\section{TORSIONAL SHEAR STRENGTH PROPERTIES OF MALAYSIAN TROPICAL TIMBER IN STRUCTURAL SIZE}

\author{
Muhammad Bazli Falia Mohd Puaada, Zakiah Ahmadb*, Adrina \\ Rosseira Abu Talipa, Mohd Zulkhairi Mat Salleha, Shahrul Nizam \\ Mohammada
}

aUiTM Cawangan Johor, Kampus Pasir Gudang, Jalan Purnama, Bandar Seri Alam, 81750 Masai, Johor Darul Takzim, Malaysia

bInstitute for Infrastructure Engineering and Sustainable

Management (IIESM), Universiti Teknologi MARA, 40450 Shah Alam,

Selangor, Malaysia
Article history

Received

5 July 2019

Received in revised form

22 May 2020

Accepted

17 June 2020

Published online

27 August 2020

*Corresponding author bazlifaliq@uitm.edu.my

\begin{abstract}
The shear strength of timber joists in timber design is important, especially to provide an adequate torsional stability and to avoid vibrational serviceability problems. In Malaysia, the data of shear strength of timber is available in MS 544: Part 2. The data were developed by shear block test with small samples without defect known as small clear samples. Torsion test is one of the other approaches that can be used to attain the state of pure shear as it does produce a purer and a clearer shear stress distribution in the specimen, allowing measurement of the pure shear properties. However, in Malaysia, very little attention has been paid to the use of the torsion test in evaluating shear strength. Therefore, this study aims to investigate the torsional shear strength of selected Malaysian tropical timbers of different strength groupings (SG) namely Balau (SG1), Kempas (SG2), Kelat (SG3), Kapur (SG4), Resak (SG4), Keruing (SG5), Mengkulang (SG5), Light Red Meranti (SG6), and Geronggang (SG7) using structural size timbers in accordance with BS: EN 408 and then compared with published by MS 554: Part 2. The result shows contradictions of strength grouping between findings and published by MS 554: Part 2. Resak (SG4) and Mengkulang (SG5) grade stress value have risen towards SG3. Geronggang is currently in the SG6. Also from the findings, Kelat (SG3), Kapur (SG4) and Keruing (SG5) grade stresses are at par towards each other, even though they are completely in the different strength group as stated in MS 544: Part 2. In conclusion, shear strength data need to be re-examined, since the strength for the tested specimen is much higher than the data given in MS 544: Part 2. This will lead to the increment in section and wastage in cost.
\end{abstract}

Keywords: Shear strength, torsion test, structural size, small clear specimen, Malaysian tropical timber

\begin{abstract}
Abstrak
Kekuatan ricih kayu dalam reka bentuk kayu adalah penting, terutama untuk memberikan kestabilan kilasan yang mencukupi dan untuk mengelakkan masalah servis getaran. Di Malaysia, data kekuatan ricih kayu terdapat di MS 544: Bahagian 2. Data dikembangkan oleh ujian blok ricih dengan sampel kecil tanpa kecacatan yang dikenali sebagai sampel kecil. Ujian kilasan adalah salah satu pendekatan lain yang dapat digunakan untuk mencapai keputusan daya ricih tulen kerana ia menghasilkan taburan kekuatan yang lebih tulen dan lebih jelas dalam spesimen, yang memungkinkan pengukuran sifat ricih yang tulen. Oleh itu, kajian ini bertujuan untuk mengkaji kekuatan ricih torsi kayu tropika Malaysia yang terpilih dari kumpulan kekuatan yang berbeza (SG) iaitu Balau (SG1), Kempas (SG2), Kelat (SG3), Kapur (SG4), Resak (SG4), Keruing (SG5), Mengkulang (SG5), Merah Merah Meranti (SG6), dan Geronggang (SG7) menggunakan kayu ukuran struktur sesuai dengan BS: EN 408 dan kemudian dibandingkan dengan yang diterbitkan oleh MS 554: Bahagian 2. Hasilnya menunjukkan percanggahan kekuatan pengelompokan antara penemuan dan diterbitkan oleh MS 554: Bahagian 2. Nilai kekuatan gred Resak (SG4) dan Mengkulang (SG5) telah meningkat ke arah SG3. Geronggang kini berada di SG6. Juga dari penemuan, tekanan kelas Kelat (SG3), Kapur (SG4) dan Keruing (SG5) setara antara satu sama lain, walaupun mereka berada dalam kumpulan kekuatan yang berbeza seperti yang dinyatakan dalam MS 544: Bahagian 2. Kesimpulannya, ricih data kekuatan perlu dikaji semula, kerana kekuatan untuk spesimen yang diuji jauh lebih tinggi daripada data yang diberikan dalam MS 544: Bahagian 2. Ini akan menyebabkan kemeningkatan kegunaan saiz kayu dan pembaziran kos.
\end{abstract}

Kata kunci: Kekuatan ricih, ujian kilasan, saiz struktur, spesimen kecil, kayu tropika Malaysia

(c) 2020 Penerbit UTM Press. All rights reserved 


\subsection{INTRODUCTION}

Shear properties timber structure consists of two types, namely shear strength and shear modulus. In order to obtain both shear strength and shear modulus data in structural size, bending and torsion tests are carefully identified to be the best options to be conducted.

Shear strength is the strength of a material or component against the type of yield or structural failure, where the material or component fails in shear. A shear load is a force that tends to produce a sliding failure on a material along a plane that is parallel to the direction of the force (1). In structural and mechanical engineering, the shear strength of a component is deemed important in designing the dimensions and materials to be used for the manufacturing or construction of the component; (2).

Numerous studies have been conducted within the past two decades involving varieties of test methods such as shear block, bending and torsion. Keenen (3) has identified that the shear block test is inappropriate for estimating the actual shear strength of structural-sized timber, as it includes stress concentrations and does not account for the influence of defects and orthotropy. Due to the variability in the timber properties, the mechanical behaviour of timber cannot be derived with any reliability from properties of small defect less timber (4). The grade stresses in Tables 1 and 2 given in MS 544 Part 2: 2001 such as tension, compression and bending stresses were obtained as a factor of small clear timber stresses. Clear timber refers to clear and defect-free small clear timber that are commonly used in laboratory investigations involving standard tests (4). Furthermore, the Code of Practice MS 544: Part 2: 2001 gives recommends obtaining the data from the structural size sample of Malaysian timbers (5).

Based from previous research, bending test is the preferred test among others, due to the simplicity of jig fabrication. Djoko et al. (1996) has conducted the investigation for different test methods in determining the shear strength of structural timber, based on full sized specimen consist of three-point, four-point, and five-point bending test, and a torsion test. This investigation is done in order to determine the relationship between the shear strength of timber and full-size specimens. Seventy-six 12 foot long with 2 by 4 inch cross-section Douglas-fir timber sample were used to conduct this study based on the ASTM D2915-94. Some significant difference among the average shear strength determined using the five different bending test methods were discovered. This is due to the fact that different test setup produces different distributions of combined stresses in the specimens. In addition, the combination of flexural and shear stresses encountered in a bending test leads to the difficulties in obtaining the true value of shear strength (6).
However, as most of the previous studies were being held abroad (European region to be precise), they have the preference towards the torsion test in order to obtain shear properties, which produces a purer and more uniform system of shear stresses in the specimen allowing measurement of the pure shear stiffness and strength. $(7,8,9,2,10)$. In addition, the studies on torsion properties of the timber are particularly important for the application of timber structure, mainly timber joist and beam. The lateral torsional buckling is the phenomenon whereby an unrestrained beam or beam-column experiences simultaneous in-plane displacement, lateral displacement and twisting. A beam that is prone to a lateral torsional buckling failure would deform under an applied load or moment until a critical moment is reached. In this regard, Gupta et al. (11) used both experimental and finite element approaches to examine the torsion test method and concluded that it is a better approach to obtain the shear strength than other methods. Considering the limitations of shear block and bending tests in determining shear strength, it would be considered unreasonable to assume that they might not be appropriate for obtaining information on the shear modulus of structural timber.

As in Malaysia, studies on shear properties on structural size timber are very scarce. Numbers of data regarding mechanical properties on structural size specimen have been produced based on this method such as bending, compression, tension and block shear strength properties $(4,5,12,13,14)$. However, San (14) has conducted a study that focused more on the obtaining the mechanical properties in accordance with ASTM D-198 of engineered timber product (LVL), rather than solid timber specimen. Furthermore, in Malaysia, testing for torsion strength of structural size timber has never been carried out, which leads to the non-availability of data regarding torsion test shear strength and shear modulus.

To conclude, there is no proper study conducted which focuses on the development of shear properties of structural size Malaysian tropical timber, especially the torsion test in accordance with EN 408: 2010. As there are substantial increments in the number of local and global timber practitioners inquiring on what are the stresses of Malaysian timber in structural form, it is deemed crucial to increase the understanding and knowledge of shear properties of the structural size Malaysian timber. The determination of strength properties of timbers in structural size obtained from the torsion test will lead to better utilization of timbers in the Malaysian construction industry.

In this paper, in the efforts for determining the shear properties particularly the shear strength, a thorough experiment using torsion tests was conducted on selected Malaysian Tropical structural timber samples. 


\subsection{METHODOLOGY}

An experimental design was performed to evaluate the torsional shear strength. There are three stages of laboratory work altogether. The first stage, involves the preparation of the timber which includes the procurement of timber logs, processing the timber and timber grading in accordance to EN 384 [15], EN 14358 [16], EN 338 [17], EN 408 [18] and BS 5756: 2011 [19]. In the second stage, a series of data collection on laboratory works were conducted to determine moisture content, density, and shear properties. In the third stage, result from the second stage was analyzed to obtain correlation between torsion tests. The shear strength was measured according to SaintVenant Theory (2). The mean and characteristic values and strength grade were evaluated according to [20]. All the data was then analyzed using statistical analysis and cumulative distribution function.

\subsection{Material}

The selected species of the solid timber used in this study were obtained from four regions of Malaysia and consisted of all nine Strength Group Timber Species as shown in Table 1. Each species of timber per strength group from SGI until SG7, except two (2) species for SG4 and SG5 accordance with MS 544: Part 2 were selected due to in-market availability and being commercially used timber species in Malaysia.

All these timbers were needed to have chain of custody (CoC) as a certificate of timber source for tracking certified material from the forest to the final product. This is done to ensure that the timber, timber fibre or non-timber forest produce contained in the product or product line can be traced back to certified forests, which will ease the process of tracking the timber from the forests through all stages of processing and distribution.

Table 1 Timber Species

\begin{tabular}{cccc}
\hline \multirow{2}{*}{ Species } & \multicolumn{2}{c}{$\begin{array}{c}\text { Mechanical properties test } \\
\text { Structural size }(\mathbf{m m})\end{array}$} & \multirow{2}{*}{ SG } \\
\cline { 2 - 3 } & \multicolumn{2}{c}{ Torsion Parallel to the grain } & \\
\cline { 2 - 3 } & Size & Amount & \\
\hline Balau & $90 \times 45 \times 1900$ & 120 & 1 \\
\hline Kempas & $90 \times 45 \times 1900$ & 120 & 2 \\
\hline Kelat & $90 \times 45 \times 1900$ & 120 & 3 \\
\hline Kapur & $90 \times 45 \times 1900$ & 120 & 4 \\
\hline Resak & $90 \times 45 \times 1900$ & 120 & 4 \\
\hline Keruing & $90 \times 45 \times 1900$ & 120 & 5 \\
\hline Mengkulang & $90 \times 45 \times 1900$ & 120 & 5 \\
\hline Light Red & $90 \times 45 \times 1900$ & 120 & 6 \\
\hline Meranti & $90 \times 45 \times 1900$ & 120 & 7 \\
\hline Geronggang & Total & 1080 & \\
\hline
\end{tabular}

These specimens were kiln dried to attain dried timber condition, as according to the Malaysian standard, it must have less than 19\% moisture content.

\subsection{Specimens Preparations and Measurements}

\subsubsection{Sample Preparation}

The specimens were prepared to the size of $90 \times 45 \times$ 1900 according to EN 384, EN 14358, EN 338 and EN 408. After the air-drying process, the timbers were graded using visual grading by professional grader from Malaysian Timber Industry Board (MTIB) and grading process was graded in accordance with BS 5756 and BS 5268: Part 2 [21]. Thus, the samples were graded as Hardwood Structural (HS) grade.

\subsubsection{Testing Procedure}

All timber beams were tested with $5 \mathrm{kN}-\mathrm{m}$ torsion testing machine, which would later be used to test the timber beams under torsion as shown in Figure 1 and Figure 2.

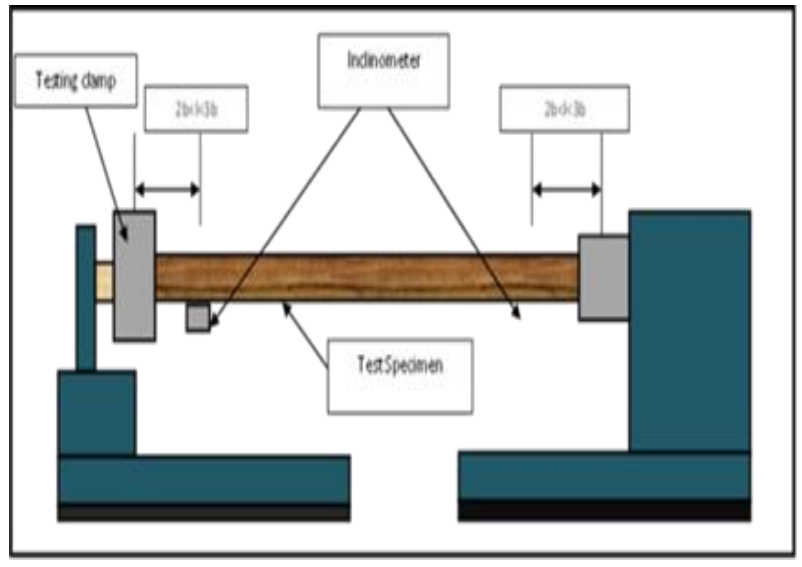

Figure 1 Schematic diagram for test setup

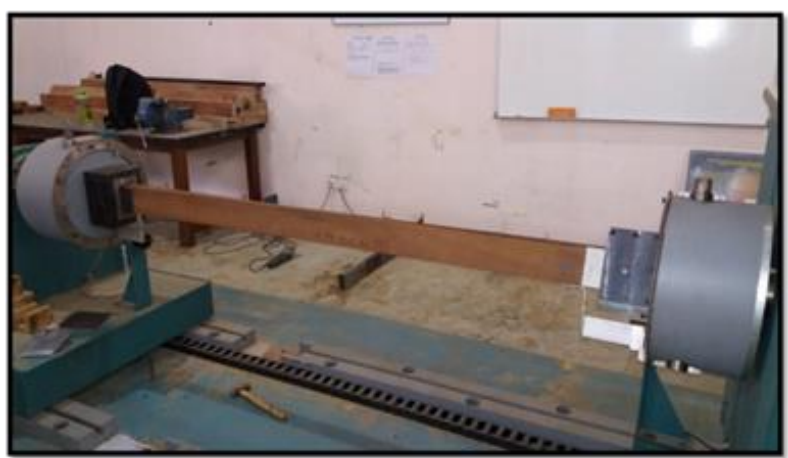

Figure 2 Machine set up for the determination of shear modulus

The test piece is clamped at the supports, which are spaced more than 16 times the largest crosssectional dimension and subjected to torsion along the longitudinal axis by a relative rotation of the supports. 
Each test specimens were tested by mounting in torsion tester and applying torque, using displacement control approach. The measurements of twist from the torsion tester will not be used for data analysis and only used to control the application of the torque as they included other components of twist in addition to the twist of the specimen itself. To measure the actual rotational displacement, two inclinometers were mounted on the downside $(45 \mathrm{~mm})$ of the specimen, which is twice the distance of the joist's depth (2d) from both clamp end. All test specimens will be tested at the rate of $20-30 \%$ min until they fractured depending on the species tested.

\subsubsection{Evaluation of the Torsion Shear Properties}

Khokhar (2) stated that torsion test can be used in determining the shear strength and can be calculated by using the simple beam theory as follow:

Shear Strength, т:

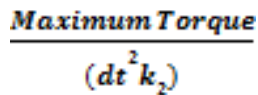

Equation 1

$\mathrm{d}$ is the depth (major cross-section dimension) and $t$ is the thickness (minor cross-section dimension) of the test specimen and $\mathrm{kl}$ and $\mathrm{k} 2$ are the constants that depend on the depth thickness ratio

\subsubsection{Grading of Timber Strength}

\section{a. Small Clear Specimen}

In Malaysia, the probability of 1 in 100 ( 1 percentile) that the minimum strength to exceed is chosen for bending, tension, compression parallel to the grain shear and modulus of elasticity (small clear specimen) (20). Therefore, for small clear specimen, the stress at 1 percentile is used. Shear strength and stiffness of timbers were analysed using cumulative distribution function. In performing the cumulative distribution function, the set of data for ultimate shear strength are needed to produce the s-curve graph and from the graph, the 1 percentile value can be determined as shown in Figure 3.

To compare the strength grouping of the timber studied with the strength grouping published in MS 544: Part 2, the basic stress and grade stress shown are needed to be determined. Basic stress is the stress that would be safely and permanently sustained by the timbers. The basic stress is determined by first determining the stress which is given in Table 2. For different types of stress, MS 544: Part 2 used different probability value.

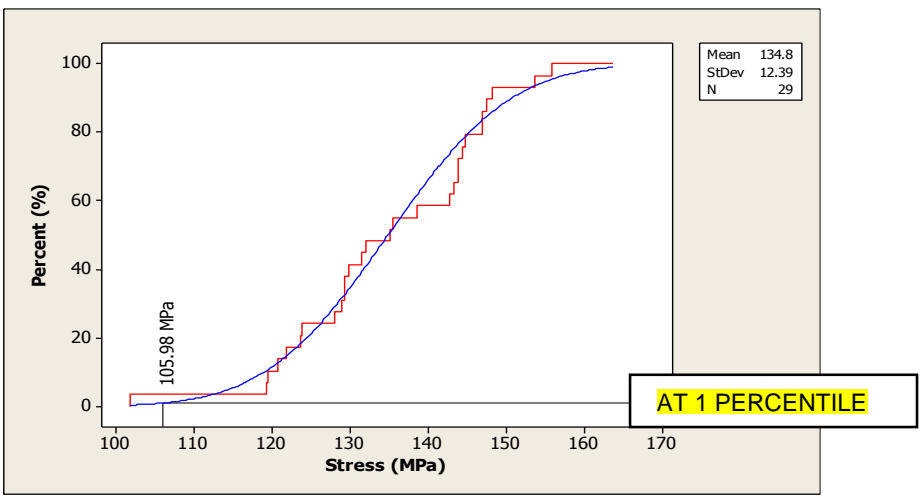

Figure 3 Cumulative Distribution Function Graph Showing the Stress at 1 Percentile

In statistics, for a probability of 1 in 100, the minimum estimated value is then divided by factor of safety according to the type of test, as shown in Table 2.

Table 2 Formula for Determining Basic Stresses (20)

\begin{tabular}{cccc}
\hline Property & $\begin{array}{c}\text { Probability } \\
\text { value }\end{array}$ & $\begin{array}{c}\text { Factor of } \\
\text { safety }\end{array}$ & Formula \\
\hline $\begin{array}{c}\text { Bending and } \\
\text { shear }\end{array}$ & 1 in 100 & 2.5 & $\frac{\frac{\mathrm{t}}{\mathrm{T}}}{2.5}$ \\
$\begin{array}{c}\text { Compression } \\
\text { parallel to the } \\
\text { grain }\end{array}$ & 1 in 100 & 1.5 & $\frac{\mathrm{T}}{1.5}$ \\
$\begin{array}{c}\text { Compression } \\
\text { perpendicular } \\
\text { to the grain }\end{array}$ & 1 in 20 & 1.3 & $\frac{\mathrm{t}}{\mathrm{x}}$ \\
\hline
\end{tabular}

This stress is called characteristic stress where,

$$
\hat{\mathrm{X}}=\text { Strengthwalue at } 1 \text { percentile or } 5 \text { percentile }
$$

To determine the grade stress, the basic stress will be multiplied by the strength ratio which is related to the percentage of defects in the timbers. There are three stress grades of timber that are associated with the different limits of strength reducing characteristics, which are known as Common, Standard and Select [20]. The strength ratios for the three grades of each strength property are given in Table 3. Design engineers are supposed to make use of the design values corresponding to the stress grade of timber in their calculations. 
Table 3 Strength Ratio

\begin{tabular}{|c|c|c|c|}
\hline Property & $\begin{array}{c}\text { Select } \\
(\%)\end{array}$ & $\begin{array}{c}\text { Standard } \\
(\%)\end{array}$ & $\begin{array}{c}\text { Common } \\
(\%)\end{array}$ \\
\hline $\begin{array}{l}\text { Bending, } \\
\text { Tension and } \\
\text { Compression } \\
\text { to Grain }\end{array}$ & 80 & 63 & 50 \\
\hline Shear & 72 & 56 & 45 \\
\hline $\begin{array}{l}\text { Modulus of } \\
\text { Elasticity }\end{array}$ & $\begin{array}{l}\text { Same } \\
\text { as the } \\
\text { basic } \\
\text { values } \\
\text { for all } \\
\text { grades }\end{array}$ & $\begin{array}{l}\text { Same as } \\
\text { the } \\
\text { basic } \\
\text { values } \\
\text { for all } \\
\text { grades }\end{array}$ & $\begin{array}{l}\text { Same as } \\
\text { the basic } \\
\text { values } \\
\text { for all } \\
\text { grades }\end{array}$ \\
\hline
\end{tabular}

\section{b. Structural Size Specimen}

For structural size specimen, the timbers were not sorted to select, standard or common categories as needed for determining the grade stress for small clear specimen. The grade stresses for structural size specimens would be based on timbers visually graded as in between common and standard (21, 22] for achieving the Hardwood Structural (HS) grade standard (BS 5756). This is the reason why the grade stresses for small clear specimen studied here were chosen from standard and better.

For the structural size specimen, the percentile used is not 1 percentile as for small clear specimens. This is because for the large size specimen, the confidence level for free from defects is less than small clear specimen. [14, 23, 24] The probability of 1 in 20 that the minimum strength is chosen for structural size specimen. Therefore, in this case, 5th percentile is used. Those values of characteristic strengths were determined directly from the s-curve graph (without multiplying with reduction factor in Table 2) of form the cumulative distribution function. The cumulative distribution function was plotted using Minitab v 16.0 software as shown Figure 4.

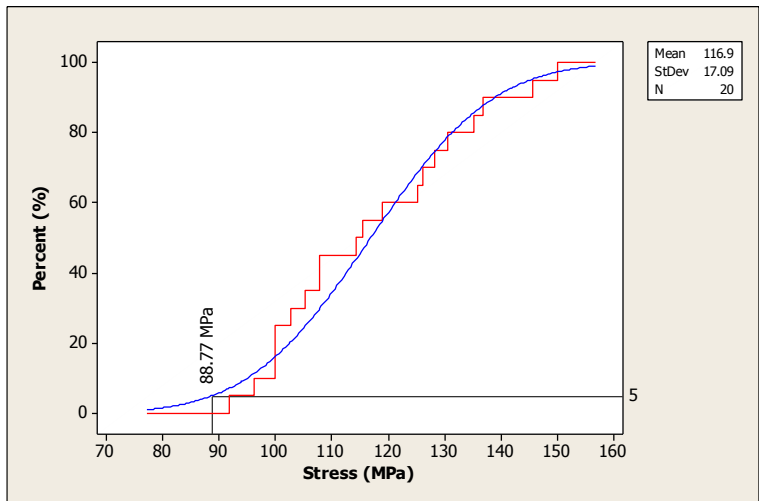

Figure 4 Cumulative Distribution Function Graph Showing the Stress at 5 Percentile

\subsection{Shear Failure Characteristics (Structural Size)}

The examples of torsional failures are shown in Table 4 with pattern and causes of failure.

Table 4 Types of failure (2)

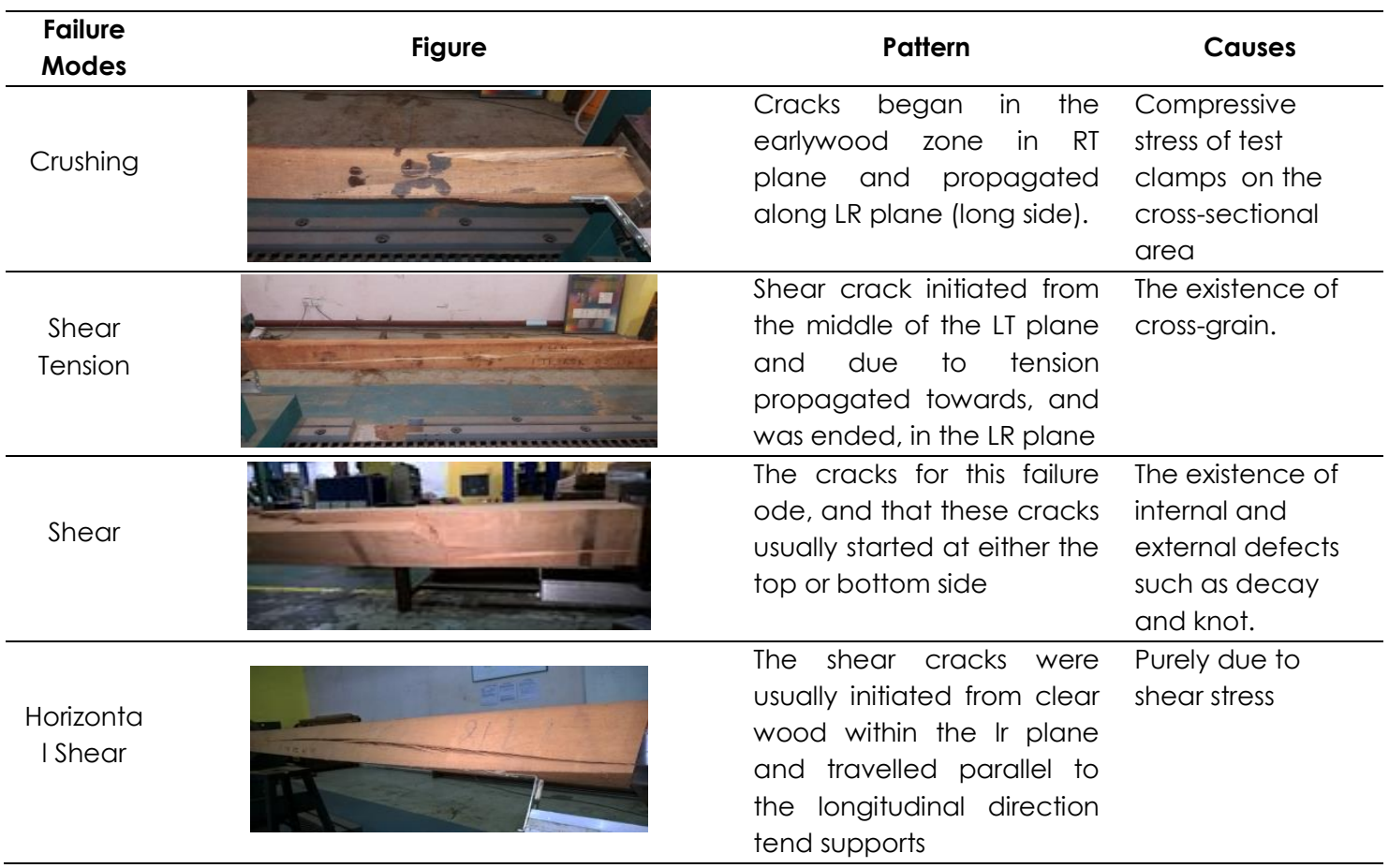


Table 5 shows the summary of failure characteristics for shear parallel to grain for structural size specimens in this study.

Table 5 Summary failure characteristic for structural size specimens under shear parallel to grain

\begin{tabular}{c|c|c|c|c}
\hline \multirow{2}{*}{ Species } & \multicolumn{4}{c}{ Percentage of Failure Modes (\%) } \\
\cline { 2 - 5 } & Crushing & $\begin{array}{c}\text { Shear } \\
\text { Tension }\end{array}$ & $\begin{array}{c}\text { Shea } \\
\mathbf{r}\end{array}$ & $\begin{array}{c}\text { Horizonta } \\
\text { I Shear }\end{array}$ \\
\hline Balau & 0.83 & 10.00 & 9.17 & 80.00 \\
\hline Kempas & 1.67 & 2.50 & 7.50 & 88.33 \\
\hline Kelat & 0.00 & 10.83 & 3.33 & 85.83 \\
\hline Kapur & 0.00 & 6.67 & 1.67 & 91.67 \\
\hline Resak & 0.00 & 9.17 & 4.17 & 86.67 \\
\hline $\begin{array}{c}\text { Keruing } \\
\text { Mengkula } \\
\text { ng }\end{array}$ & 0.00 & 4.17 & 0.83 & 95.00 \\
\hline $\begin{array}{c}\text { Light Red } \\
\text { Meranti }\end{array}$ & 0.83 & 5.83 & 4.17 & 89.17 \\
\hline $\begin{array}{c}\text { Gerongg } \\
\text { ang }\end{array}$ & 0.83 & 10.00 & 9.17 & 80.00 \\
\hline
\end{tabular}

By referring to Table 5, it shows that generally the beam failed in horizontal shear, followed by shear tension, shear and crushing.

It shows that more than $80 \%$ of horizontal shear failure develops to all species, which is a good indicator for this study. About less than $10 \%$ of failure developed by shear tension and shear due to defects. The percentages of failure due to defects were considered small since these timbers were graded as Hardwood Structural (HS) grade.

Bodig and Jayne (25) stated that an usual complex distribution of stresses in the material that are is to internal inhomogeneties, also known as defects is responsible for this behavior and causes the deficiency in mechanical properties in timber, which is for sure will cause the reduction of mechanical properties. Table 6 shows the relationship between failure type and mean torque.

Referring to Table 6, crushing failure produces the maximum value of mean torque $727 \mathrm{kN}$. However, compressive stresses from the clamp that are not developed by the samples were identified as the contributing factor. The comparison between three types of shear failure; horizontal shear produces the highest mean torque of $651.35 \mathrm{kN}$, followed by shear tension with $617.94 \mathrm{kN}$ and shear with the value of $604.09 \mathrm{kN}$. This indicates that the mean torque values are aligned with the type of failures and its causes.
Table 6 Summary failure characteristic for structural size specimens under shear parallel to grain

\begin{tabular}{ccc}
\hline Failure Type & Number & $\begin{array}{c}\text { Mean } \\
\text { Torque (N) }\end{array}$ \\
\hline Crushing & 5 & 727000 \\
\hline $\begin{array}{c}\text { Shear } \\
\text { tension }\end{array}$ & 73 & 617945.30 \\
\hline Shear & 47 & 604085.10 \\
\hline $\begin{array}{c}\text { Horizontal } \\
\text { Shear }\end{array}$ & 955 & 651354.97 \\
\hline
\end{tabular}

\subsection{Characteristic of Shear Strength}

Table 7 shows the shear strength and physical properties of large size specimens. All the mean values of moisture content for all species are in the range $9 \%$ to $13 \%$. Since all mean value of moisture content is lower than $19 \%$ the samples are therefore classified as dry species, which has been stated in MS 544: Part 2. As for density, it indicates that the strength depends on the density of timbers. The higher the density, the higher the strength is.

By referring to Table 7 and Figure 5, the shear strength values are in the following order: Balau > (Kempas, Resak and Mengkulang) > (Kelat, Kapur and Keruing) > Geronggang > Light Red Meranti. This result also suggests that Kempas, Resak, Mengkulang and Kelat, Kapur, Keruing should be in the same strength category.

To conclude, it shows that the Resak, Menkulang and Geronggang have greater separation in the distribution of the species in their strength group. Resak and Mengkulang distributions of strength tend to move towards the SG 2 species which means higher in strength grouping. On the other hand, Resak and Mengkulang distributions of strength are greater than Kelat, Kapur and Keruing, which are in between SG 4 and SG 5. As for the Geronggang, it tends to shift towards SG6 strength group which is higher than Light Red Meranti.

Based on the result, there are a lot of contradictions as compared to the strength group provided by MS 544: Part 2 [26]. 
Table 7 Summary for Mean Shear Strengths of Large Size Specimens

\begin{tabular}{|c|c|c|c|c|c|}
\hline \multirow{3}{*}{ Species } & \multicolumn{3}{|c|}{ Large Size Specimen } & \multirow{3}{*}{$\begin{array}{l}\text { Density } \\
\text { (Kg/m3) }\end{array}$} & \multirow{3}{*}{$M C(\%)$} \\
\hline & \multicolumn{3}{|c|}{ Shear Strength } & & \\
\hline & $\begin{array}{l}\text { Mean } \\
(\text { Mpa) }\end{array}$ & $\begin{array}{c}\text { Standard } \\
\text { Deviation } \\
\text { (Mpa) }\end{array}$ & $\operatorname{cov} \%$ & & \\
\hline Balau & 8.36 & 1.44 & 17.27 & 1075.95 & 14.32 \\
\hline Kempas & 7.51 & 1.25 & 16.65 & 865.32 & 13.24 \\
\hline Kelat & 5.89 & 0.88 & 14.81 & 938.79 & 14.08 \\
\hline Kapur & 5.83 & 0.76 & 13.13 & 807.29 & 13.97 \\
\hline Resak & 7.52 & 1.45 & 19.28 & 942.26 & 12.98 \\
\hline Keruing & 5.52 & 0.77 & 13.82 & 869.89 & 14.31 \\
\hline Mengkulang & 6.74 & 1.15 & 17.14 & 758.93 & 14.05 \\
\hline $\begin{array}{l}\text { Light Red } \\
\text { Meranti }\end{array}$ & 4.32 & 0.50 & 11.53 & 477.34 & 13.22 \\
\hline Geronggang & 4.82 & 0.71 & 14.58 & 555.47 & 13.62 \\
\hline
\end{tabular}

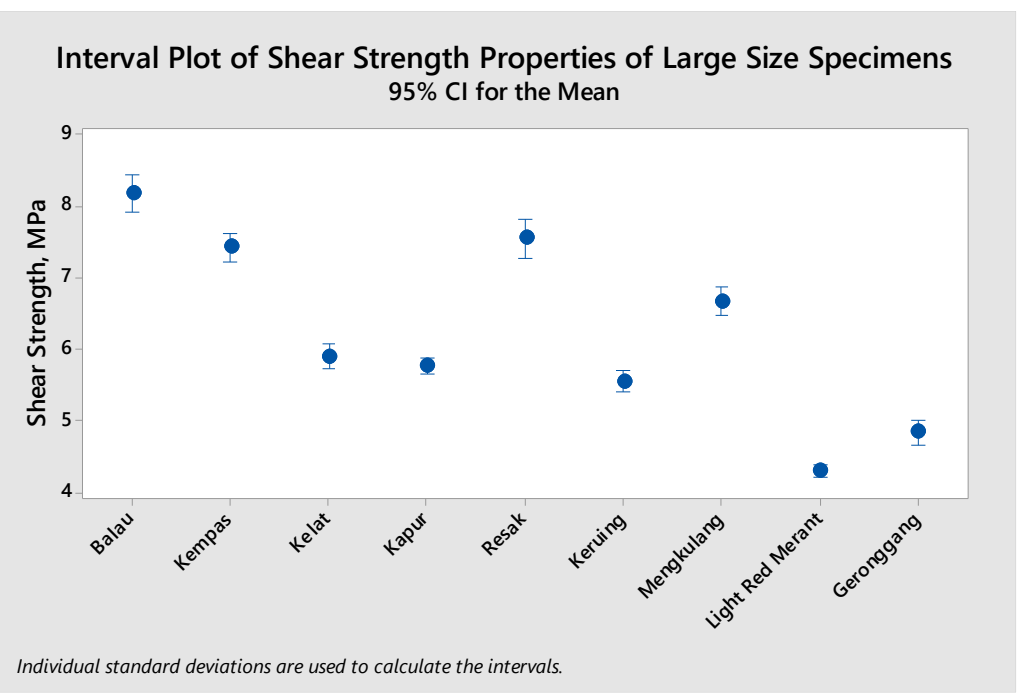

Figure 5 Interval Plot of Shear Strength Properties of Large Size Specimens

\subsection{Grade Shear Strength}

Referring to Figure 6, which presents the Distributions of Strength at 5 Percentile of Species as a Cumulative Distribution Function for Shear Strength, there are changes in strength distribution, which is almost similar to the result presented from Table 7 and Figure 5. The cumulative distribution function provides initial information on the strength properties of the timbers. 


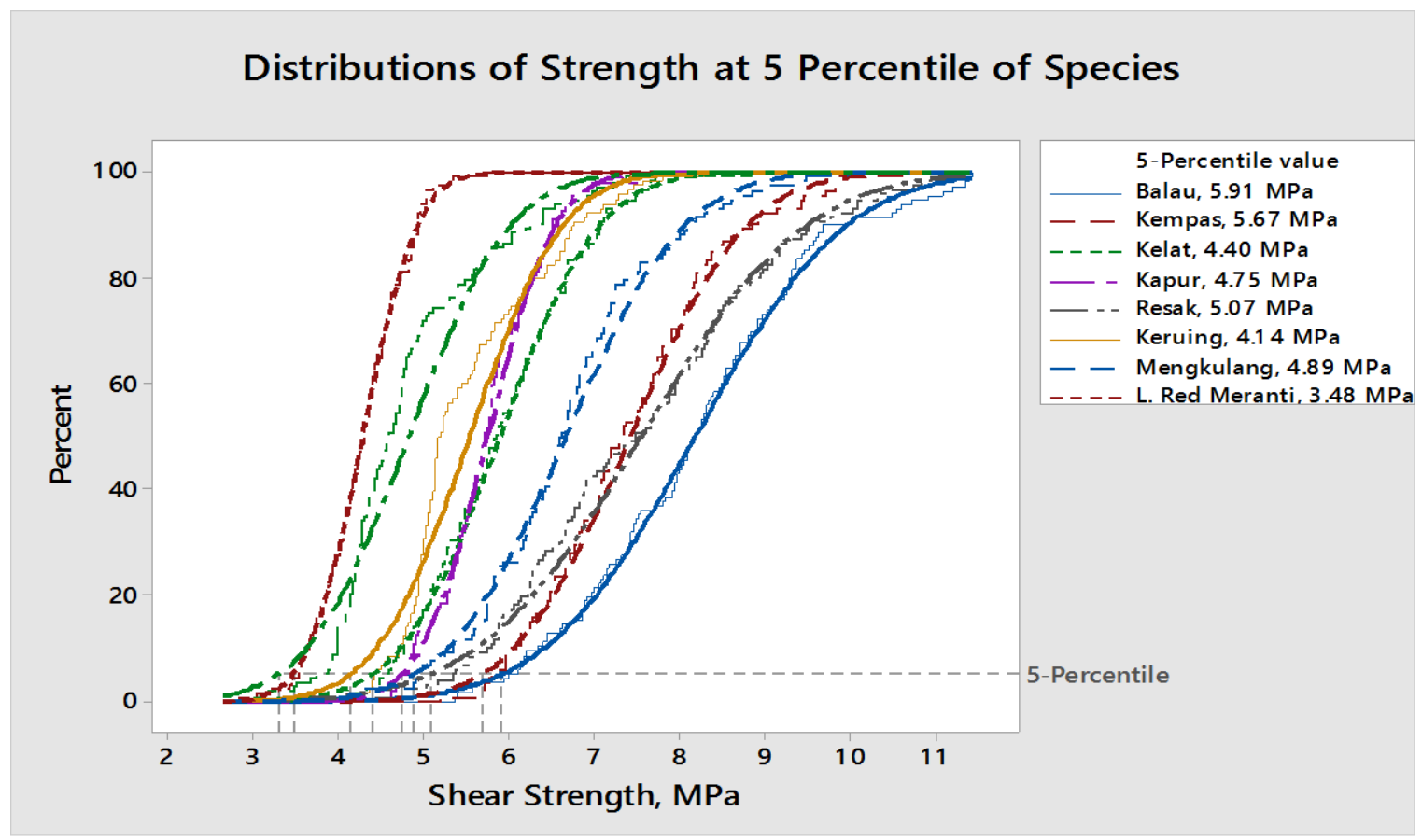

Figure 6 Distributions of Strength at 5 Percentile of Species as a Cumulative Distribution Function for Torsional Shear

Table 8 shows the grade stresses of torsional shear strength in structural size. From Table 8 , it was found that Balau, Kempas and Resak recorded the highest values of shear strength of $2.36 \mathrm{MPa}, 2.27 \mathrm{MPa}$ and $2.03 \mathrm{MPa}$ respectively. Meanwhile, Light Red Meranti and Geronggang have the lowest values of of 1.39 $\mathrm{MPa}$ and $1.36 \mathrm{MPa}$. As for Mengkulang, the grade stress $(1.96 \mathrm{MPa})$ of the large size specimen is much higher than SG3-SG5 species namely Kelat (1.76 $\mathrm{MPa})$, Kapur (1.90 MPa) and Keruing (1.66 MPa), whereas Mengkulang is in SG 5.

In terms of comparison between MS 544: Part 2 Standard Grade stress data and structural size in term of shear strength, the value given in structural size is much higher for all timber species. The results is in good agreement with Branco et al. (27), where the bending strength of the structural specimen has greater value between the bending strength provided in the DNA-ECS (Portuguese Nationally Determined Parameters of Eurocode 5) based on the small clear specimen. Furthermore, Puaad (4) has conducted a bending and compression test on structural size to determine both bending and compressive strength of full-size and concluded that the strength of the structural specimen is larger compared to small clear specimen.

One difficulty in predicting the strength of Malaysian timbers, under the same species is that the density may vary in wide range. The grade stress is stated in MS 544: Part 2 group with minimum properties including the density. The density of each species for structural size specimen in bending is about the same with the density of small clear specimen.

Table 8 Summary Statistic for Shear Strength

\begin{tabular}{|c|c|c|c|c|c|c|}
\hline \multirow[b]{2}{*}{ Species } & \multicolumn{6}{|c|}{ Shear Strength } \\
\hline & $\begin{array}{l}\text { Mea } \\
\mathrm{n}, \overline{\mathrm{x}} \\
(\mathrm{MP} \\
\mathrm{a})\end{array}$ & StDev, $\sigma$ & $5^{\text {th }}$ Percentile & 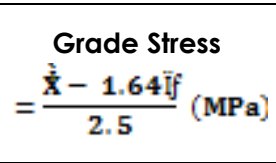 & $=\frac{\begin{array}{c}\text { Grade Stress } \\
5^{\text {thPercentile }}\end{array}}{2.5}(\mathrm{MPa})$ & $\begin{array}{c}\text { MS } 544 \text { Part } 2 \\
\text { Standard Grade stress } \\
\text { (MPa) }\end{array}$ \\
\hline Balau & 8.18 & 1.38 & 5.91 & 2.37 & 2.36 & 2.08 \\
\hline Kempas & 7.43 & 1.07 & 5.67 & 2.27 & 2.27 & 1.74 \\
\hline Kelat & 5.90 & 0.91 & 4.4 & 1.76 & 1.76 & 1.68 \\
\hline Kapur & 5.76 & 0.62 & 4.75 & 1.90 & 1.90 & 1.33 \\
\hline Resak & 7.55 & 1.51 & 5.07 & 2.03 & 2.03 & 1.40 \\
\hline Keruing & 5.55 & 0.85 & 4.14 & 1.66 & 1.66 & 1.06 \\
\hline Mengkulang & 6.673 & 1.08 & 4.89 & 1.96 & 1.96 & 1.45 \\
\hline $\begin{array}{c}\text { Light Red } \\
\text { Meranti }\end{array}$ & 4.30 & 0.50 & 3.48 & 1.39 & 1.39 & 0.82 \\
\hline Geronggang & 4.83 & 0.93 & 3.3 & 1.32 & 1.32 & 0.85 \\
\hline
\end{tabular}




\subsection{CONCLUSION}

This paper has presented the results of torsional shear strength from Malaysian Tropical Timber. The findings are four types of failure pattern obtained from the test, namely horizontal shear (most occurred), followed by tension shear, shear and crushing. The relationship between failure pattern and characteristic stress shows that horizontal shear produced the highest characteristics shear stress due to the development of pure shear failure of the sample. It is then followed by tension shear and shear, which occur mostly due to the internal and external defects. Crushing failure pattern is very rare, in terms of occurrence with the rate of below $1 \%$. It is due to the testing clamps, which have induced additional compressive stresses that lead to crushing effect on the samples. Furthermore, the structural size of torsional grade shear stress has been seen to produce higher strengths than values published by MS544: Part 2 based on shear block tests. Lastly, there are contradictions of strength grouping between findings and published by MS554: Part 2. Resak (SG4) and Mengkulang (SG5) grade stress value has risen towards SG 3. Geronggang is currently in the SG6. Also from the findings, Kelat (SG3), Kapur (SG4) and Kerving (SG5) grade stresses are at par towards each other, even though they are completely in the different strength group as stated in MS544: Part 2.

The conclusion that can be drawn is that the torsional shear strength size for density specimen needs to be re-examined, since the strength for the tested specimen is much higher than the data given in MS 544 Part 2. This will lead to the increment in section and wastage in cost if the designer only refers to the strength properties produced by small clear specimens.

\section{Acknowledgement}

This research is fully supported by FRGS grant, 600IRMI/FRGS 5/3 (0113/2016). The authors fully acknowledged Ministry of Higher Education (MOHE) and Universiti Teknologi MARA for the approved fund which makes this important research viable and effective.

\section{References}

[1] USDA. 1999. Wood Handbook: Wood as an Engineering Material. US Department of Agriculture and Forest Product Laboratory, Madison, WI, USA.

[2] Khokhar, A. M. 2011. The Evaluation of Shear Properties of Timber Beams Using Torsion Test Method. Doctor of Philosophy. Edinburgh Napier University Edinburgh, Scotland, United Kingdom.

[3] Keenen, F. J. 1974. Shear Strength of Wood Beams. Forest Products Journal. 24(09): 63-70.

[4] Puaad, M. B. F. M. 2013 Bending and Compressive Properties of Malaysian Timber in Structural Size. Master of
Science Thesis. Faculty of Civil Engineering. Universiti Teknologi Mara, Shah Alam, Selangor. Malaysia.

[5] Ahmad, Z., Bon, Y. C., Wahab. E. S. A. 2003. Tensile Strength Properties of Tropical Hardwoods in Structural Size Testing. International Journal of Basic \& Applied Sciences IJBAS-IJENS. 10(03).

[6] Vafai, A., Pinus, G. 1973. Torsional and Bending Behaviour of Wood Beams. ASCE Journal of Structural Engineering. 99(ST6): 1205-1221.

[7] Divos, F., Tanaka, T., Nagao, H., Kato, H. 1998. Determination of Shear Modulus on Sonstruction Size Timber. Wood Science and Technology. 32(06): 393-402.

[8] Yoshihara, H., Furushima, T. 2003. Shear Strengths of Wood Measured by Various Short Beam Shear Test Methods. Wood Science and Technology. 37(03): 188-197.

[9] Ido, H., Nagao, H., Kato, H. 2007. Comparison between Compression Strength Perpendicular to the Grain and Shear Strength Parallel to the Grain of Western Hemlock [Tsuga Heterophylla] Lumber. Bulletin of the Forestry and Forest Products.

[10] Ahmad, Z. 2013. Laminated Veneer Lumber Made from Tropical Forest Trees (Mechanical Properties). UiTM Press. UiTM Shah Alam, Malaysia.

[11] Gupta, R., Heck, L. R., Miller, T. H. 2002. Experimental Evaluation of the Torsion Test for Determining Shear Strength of Structural Lumber. Journal of Testing and Evaluation. 30(4): 283-290.

[12] Ahmad, Y. 2010. Bending Behavior of Timber Beams Strengthened Using Fiber Reinforced Polymer Bars and Plates. Doctor of Philosophy Thesis. Faculty of Civil Engineering, Universiti Teknologi Malaysia. Johor. Malaysia.

[13] Hassan, R., Ahmad, Z., Ibrahim, A., Noh, M. S. 2004. Compresisive Strength Properties of Structural Size Timber Made from Selected Malaysian Tropical Timber. Institute Penyelidikan, Pembangunan dan Komersilan, Universiti Teknologi Mara, Shah Alam, Malaysia.

[14] San, H. P. 2003. Basic Engineering Properties of Laminated Veneer Lumber (LVL) Produced from Tropical Hardwood Species. Doctor of Philosophy Thesis. Faculty of Forestry Universiti Putra Malaysia. Selangor. Malaysia.

[15] EN384:2003. 2003. Structural Timber-determination of Characteristic Values of Mechanical Properties and Density. European Committee for Standardization, Brussels, Belgium.

[16] EN14358:2016. 2016. Timber Structures - Calculation and Verification of Characteristic Values.

[17] EN338:2009. 2009. Timber Structures - Strength Classes. European Committee for Standardization, Brussels, Belgium.

[18] EN408:20010. 2010. Timber Structures - Structural Timber and Glued Laminated Timber - Determination of Some Physical and Mechanical Properties Perpendicular to the Grain. European Committee for Standardization, Brussels, Belgium.

[19] BS 5756:2011. 2011. Visual Grading of Hardwood Specification

[20] Chu, Y. P., Ho, K. S., Midon, M. S., Malik, A. R. A. 1997. Timber Design Handbook. FRIM, Malaysia. Kepong.

[21] BS 5268-2:2002. Structural Use of Timber - Part 2: Code of Practice for Permissible Stress Design, Materials and Workmanship.

[22] MS 544 Part 3: 2001. Code of Practice for the Structural Use of Timber Part 3: Permissible Stress Design of Glued Laminated Timber.

[23] NZW. 2007. Information Sheet. Grading Systems for Structural Timber.

[24] Säll, H., Källsner, B., Olsson, A. 2007. Bending Strength and Stiffness of Aspen Sawn Timber. COST E 53 Conference Quality Control for Wood and Wood Products. 15th - 17th October 2007, Warsaw, Poland.

[25] Bodig, J. and Jayne, B. A. 1982. Mechanics of Woods and Wood Composite. Van Nostrand Reinhold Company Inc. New York. United States. 
[26] MS 544 Part 2: 2001. Code of Practice for Structural Use of Timber. Department of Standard. Malaysia. Department of Standard. Malaysia.
[27] Branco, J., Varum, H., Cruz, P. 2006. Structural Grades of Timber by Bending and Compression Tests. Materials Science Forum Vols. 514-516, Portugal. 1663-1667. 